Şerif Can HATİPOĞLU

Doktora Öğrencisi| Ph. D. Student Ondokuz Mayıs Üniversitesi, Lisansüstü Eğitim Enstitüsü, Coğrafya Anabilim Dalı, Samsun-TÜRKIYYE Ondokuz Mayis University, Postgraduate Education Institute, Department of Geography, Samsun-TURKEY ORCID: 0000-0003-3425-6840 serifcanhatipoglu@gmail.com

\title{
Ordu İlinin Doğaya Dayalı Turizm Olanaklarının "Doğa Temelli Turizm İçin Doğal Kaynakların Ölçümü Modeli” ile Değerlendirilmesi ${ }^{1}$
}

Öz

Bu çalışmada Ordu ilinin doğaya dayalı turizm olanakları ölçülmüştür. Yakın zamanda kitle turizmine alternatif olarak ortaya çıkan türlerden olan doğaya dayalı turizmin önemi artmaktadır. Çalışmada doğaya dayalı turizm olanaklarının ölçümü için “Doğa Temelli Turizm İçin Doğal Kaynakların Ölçümü” modeli kullanılırken arazi çalışmaları ile ilçelerde incelemeler yapılmış ve fotoğraflar çekilmiştir. Kaynak ve literatür taramasıyla model desteklenmiştir. Harita üretiminde ArcGIS 10.4 programı kullanılmıştır. Ordu iline uygulanan "Doğa Temelli Turizm İçin Doğal Kaynakların Ölçümü” modeli sonuçlarına göre Perşembe ilçesi yüksek; Altınordu, Fatsa, Ünye, Gülyalı, Kabadüz, Akkuş, Kumru, Korgan, Çamaş, Gölköy, Ulubey, Mesudiye, Aybastı ilçeleri orta düzeyde; Çaybaşı, İkizce, Çatalpınar, Kabataş, Gürgentepe ilçeleri ise düşük çekicilik çeşitliliğine sahiptir. Çekicilik çeşitliliklerin sayısında Altınordu "34” puanla en yüksek, Kabataş ise 0" puanla en düşük puana sahip ilçelerdir. Ulaşılabilirlik bakımından Çaybaşı, İkizce, Akkuş, Kumru, Korgan, Çatalpınar, Kabataş, Aybastı 8'er puanla orta-iyi; Kabadüz, Çamaş, Gürgentepe, Gölköy, Ulubey 9'ar ve Altınordu, Fatsa, Ünye, Gülyalı, Mesudiye ilçeleri ise 10'ar puanla iyi erişim sınıfındadır. Destekleyici altyap1 kategorisinde Altınordu, Fatsa, Ünye 10'ar, Perşembe, Gülyalı, Gölköy, Kabadüz 9'ar; Aybastı, Ulubey, Mesudiye 8'er; Akkuş, Çamaş, Gürgentepe 7'şer; Kumru, Korgan, Çaybaşı, İkizce 6'şar; Çatalpınar, Kabataş ilçeleri ise 5'er puana sahiptir. Çevresel bozulma kategorisinde Altınordu, Fatsa, Ünye, Gülyalı, Perşembe, İkizce, Korgan, Kumru, Aybastı, Akkuş, Mesudiye, Gölköy, Gürgentepe, Çamaş, Kabataş, Çatalpınar, Ulubey aldıkları puanlarla düşük; Çaybaşı, Kabadüz ilçeleri ise düşük-orta düzeyde çevresel bozulma sınıfındadır. Kaynakların bölgesel önem düzeyi kategorisinde en yüksek puana Aybastı ve Kabadüz ilçeleri sahipken Altınordu, Perşembe ve Mesudiye ilçeleri de önemli turistik kaynak sahaları olmuştur. Fatsa, Ünye, Gülyalı, Akkuş, Kumru, Korgan, Çamaş, Gürgentepe, Gölköy, Ulubey ise aldıkları puanlara göre orta seviye; İkizce, Çaybaşı, Kabataş, Çatalpınar ilçeleri ise en düşük önem düzeyine sahip sahalar olmuştur. Sahada çekicilik çeşitliliği zayıf ilçeler gruplandırılarak güzergâhlar belirlenmelidir. Özellikle Kabataş ve Çatalpınar ilçelerinin eksik altyapı ve destek sistemleri tamamlanmalıdır. Sahadaki katı atık, kontrolsüz yapılaşma ve heyelan problemleri için önlemler alınmalıdır.

Anahtar Sözcükler: Doğa, Turizm, Coğrafya, Ordu, Türkiye.

\section{Evaluation of the Nature-Based Tourism Opportunities of Ordu Province with the "As- sessment of Natural Resources for Nature-Based Tourism"}

\begin{abstract}
In this study, nature-based tourism opportunities of Ordu province were measured. The importance of nature-based tourism, which has recently emerged as an alternative to mass tourism, is increasing. In the study, the "Measurement of Natural Resources for Nature-Based Tourism" model was used to measure nature-based tourism opportunities, while surveys were made in the districts with field studies, and photographs were taken. The model was supported by the source and literature review. ArcGIS 10.4 program was used in map production. According to the results of the "Measurement of Natural Resources for Nature-Based Tourism" model applied to Ordu province, the district of Perşembe is high, and the districts of Altınordu, Fatsa, Ünye, Gülyalı, Kabadüz, Akkuş, Kumru, Korgan, Çamaş, Gölköy, Ulubey, Mesudiye, Aybastı are at medium level, and Çaybaşı, İkizce, Çatalpınar, Kabataş and Gürgentepe districts have low attractiveness diversity. In the number of attractiveness diversity, Altınordu has the highest score
\end{abstract}

\footnotetext{
${ }^{1}$ Bu çalışma yazarın hazırlamakta olduğu "Ordu İli Turizm Coğrafyası" adlı doktora tezinin bir bölümünden üretilmiştir.
} 
with “34”, and Kabataş has the lowest score with “0” points. In terms of accessibility, Çaybaş1, İkizce, Akkuş, Kumru, Korgan, Çatalpınar, Kabataş, Aybastı are average-good with 8 points, Kabadüz, Çamaş, Gürgentepe, Gölköy, Ulubey with 9 points and Altınordu, Fatsa, Ünye, Gülyalı, Mesudiye districts with 10 points are in the best access class. In the supporting infrastructure category, Altınordu, Fatsa, Ünye 10 each, Perşembe, Gülyalı, Gölköy, Kabadüz 9 each, Aybastı, Ulubey, Mesudiye 8 each, Akkuş, Çamaş, Gürgentepe 7 each, Kumru, Korgan, Çaybaş1, İkizce 6 each and Çatalpinar and Kabataş districts each have 5 points. In the environmental degradation category, Altınordu, Fatsa, Ünye, Gülyalı, Perşembe, İkizce, Korgan, Kumru, Aybastı, Akkuş, Mesudiye, Gölköy, Gürgentepe, Çamaş, Kabataş, Çatalpınar, Ulubey districts have low scores, while Çaybaşı and Kabadüz districts have low-medium scores. While Aybastı and Kabadüz districts have the highest scores in the regional importance level of resources category, Altınordu, Perșembe and Mesudiye districts have also seem to be important touristic resource areas. Fatsa, Ünye, Gülyalı, Akkuş, Kumru, Korgan, Çamaş, Gürgen-tepe, Gölköy, Ulubey are the areas with the medium level, while İkizce, Çaybaşı, Kabataş, Çatalpınar districts are the areas with the lowest level of importance. The routes should be determined by grouping the districts with low attractiveness diversity in the field. Especially the missing infrastructure and support systems of Kabataş and Çatalpınar districts should be completed. Measures should be taken for solid waste, uncontrolled construction and landslide problems in the field.

Keywords: Nature, Tourism, Geography, Ordu, Turkey.

\section{Giriş}

Dünyada ve ülkemizde turizm yaygın olarak kitle turizmi şeklinde gelişme göstermiştir (Doğaner, 1994, s. 96). Daha çok kâr odaklı olan bu turizm şekli doğal çevrenin korunması ve sürdürülebilirliği bakımından olumsuz etkilere sahip olduğundan son yıllarda alternatif turizm türleri popüler hâle gelmeye başlamıştır. Son zamanlarda yaşanan pandemi de alternatif turizme olan ilgiyi arttıran önemli bir faktör olarak göze çarpmaktadır. Bunun en önemli sebebi hiç şüphesiz alternatif turizm türlerinin kitle turizmine nazaran daha küçük gruplar hâlinde ya da bireysel olarak gerçekleştirilebilmesidir. Alternatif turizm çevreye duyarllılı prensibini bünyesinde barındırdığından ekolojik turizmin kapsamına da girmektedir (Pirselimoğlu Batman \& Demirel, 2015, s. 14). Alternatif turizm türlerinden biri olan doğa temelli turizm, doğa turizmi ya da eko turizm olarak da bilinmektedir (Boo, 1990'a atfen Luzar et al., 1995, p. 544). Doğa temelli turizm içerisinde kültürel oluşumları da barındıran, nispi olarak bozulmamış ve kirletilmemiş doğal sahalara, manzara ve içerisindeki vahşi bitki ve hayvan varlığı üzerine çalışmak, tadını çıkarmak ve hayran olmak gibi bazı sebeplerle gerçekleştirilen seyahatler olarak tanımlanmaktadır (Boo, 1990'a atfen Luzar et al., 1995, p. 544).

Türkiye'de özellikle Karadeniz Bölgesi sahip olduğu nispeten bozulmamış doğal coğrafi ortamı yanı sıra içerisinde barındırdığı çok sayıda doğal turistik kaynak ile doğaya dayalı turizm bakımından zengin ve çok çeşitli olanaklara sahiptir. Ordu ili de sahip olduğu çok sayıda doğal turistik kaynak ile bu zenginliğin önemli bir parçasını oluşturmaktadır (Fotoğraf 1). Bu çalışmanın amacı, Ordu ilinin doğaya dayalı turizm olanaklarının değerlendirmenin yanında mevcut ve tespit edilebilecek eksikliklere yönelik öneriler getirmektir. Bu çalışmada Ordu ilindeki doğa temelli turizm olanakları Priskin (2001) tarafından geliştirilen "Doğa Temelli Turizm İçin Doğal Kaynakların Ölçümü (Assessment of Natural Resources for Nature-based Tourism) modeli ile değerlendirilmiştir.

Dünyada doğaya dayalı turizm konusu ile ilgili birçok akademik çalışmanın yapıldığını görmek mümkündür (Fredman \& Margaryan, 2021, s. 14; Winter et al., 2019, p. 1; Verbos et al., 2017, p. 1; Priskin, 2001, p. 637; Luzar et al., 1995, p. 544; 14; Boo, 1990, p. 1). Aynı zamanda ülkemizde yapılan çalışmalarda da örneklere rastlanmaktadır (Arslan, 2019, s. 332; Koday vd., 2018, s. 124; Acuner \& Tayfun, 2016, s. 63; Köroğlu \& Karaman, 2014, s. 95; Turoğlu \& Özdemir, 2005, s. 97; Doğaner, 1994, s. 96). Literatür taraması sırasında araştırma sahasıyla ilgili bu konuya değinen bazı çalışmalar tespit edilmiştir (Güler, 2021, s. 55; Hatipoğlu \& Bahadır, 2020, s. 548; Şengül vd., 2019, s. 23; Bahadır \& Işı1, 2018, s. 92; Bahtiyar Karadeniz \& Sarı, 2018, s. 741; Bahtiyar Karadeniz vd., 2018, s. 323; Koday \& Kiz1lkan, 2018, s. 94; Bahtiyar Karadeniz, 2014, s. 84). 
Hatipoğlu, Ş. C. (2021). Ordu ilinin doğaya dayalı turizm olanaklarının “doğa temelli turizm için doğal kaynakların ölçümü modeli” ile değerlendirilmesi, Mavi Atlas, 9(2), 92-107

Fotoğraf 1. Ordu ilindeki doğal turistik çekiciliklerden bazı örnekler [1-Ulugöl Tabiat Parkı (Gölköy), 2Küpkaya Yatak İçi Şekilleri (Ulubey), 3- Perşembe Yaylası (Aybastı), 4- Karaoluk (Çiseli) Şelalesi (Altınor$\mathrm{du})]$.

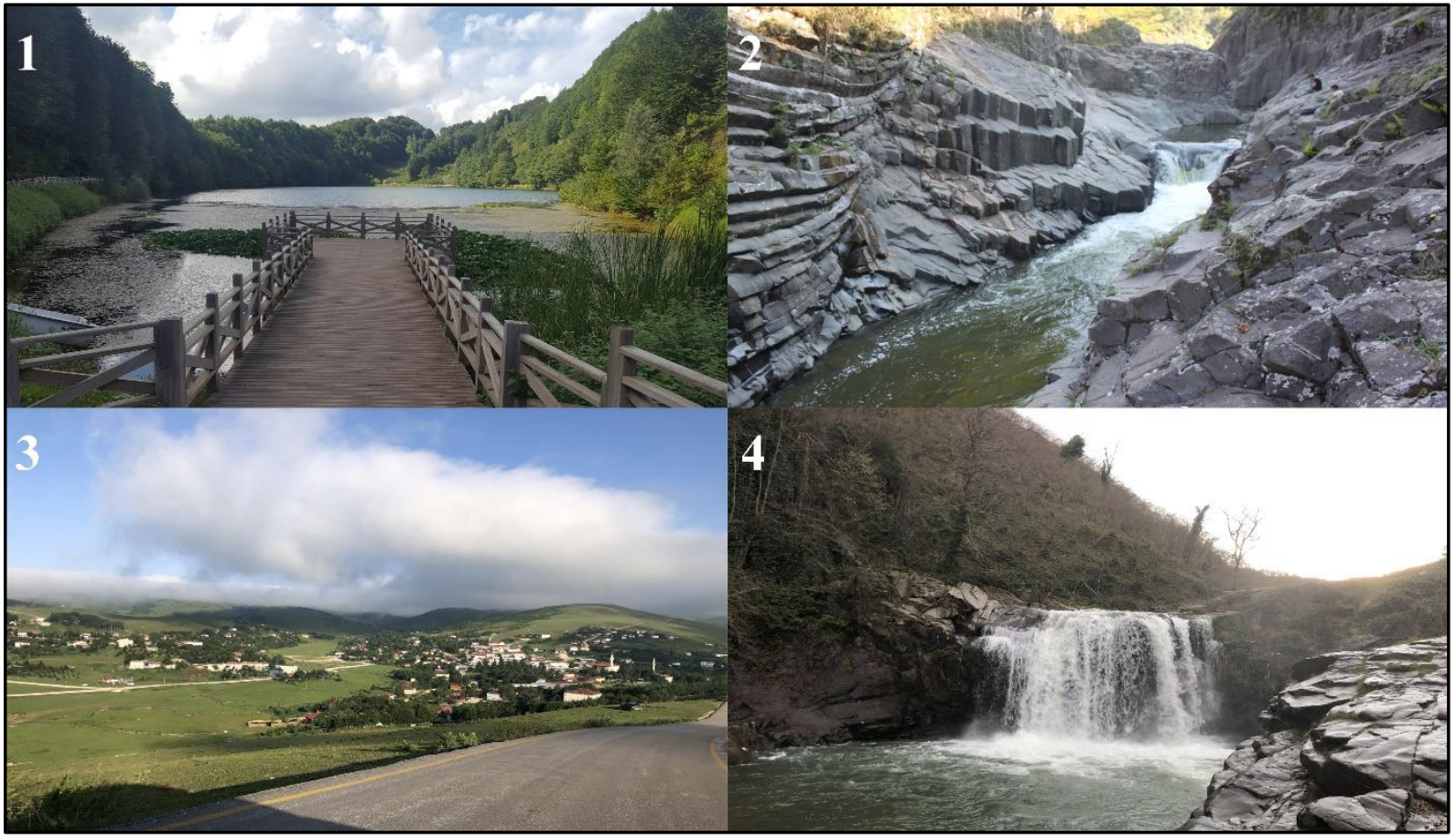

Şekil 1. Araştırma sahasının lokasyon haritası.

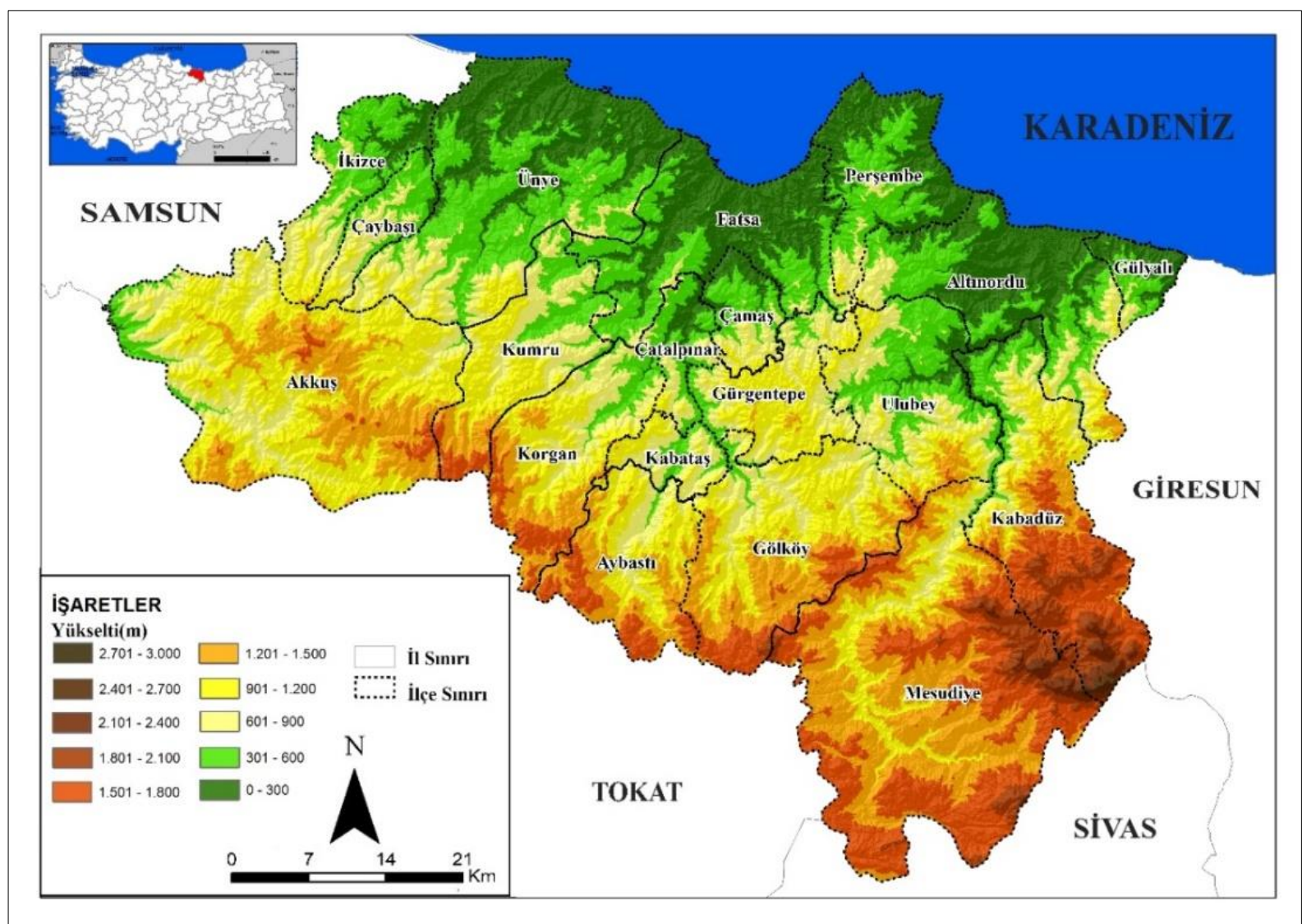


Hatipoğlu, Ş. C. (2021). Ordu ilinin doğaya dayalı turizm olanaklarının "doğa temelli turizm için doğal kaynakların ölçümü modeli” ile değerlendirilmesi, Mavi Atlas, 9(2), 92-107

Araştırma sahasının kapsamı Ordu ili idari sınırlarıdır. Doğusunda Giresun, batısında Samsun, güneyinde Tokat ile Sivas illeri ve kuzeyinde Karadeniz ile çevrilidir (Şekil 1). Çalışma alanı Karadeniz Bölgesi'nde, Orta ve Doğu Karadeniz bölümlerinin kesişim alanında yer almaktadır. Araştırma sahasının toplam yüz ölçümü yaklaşık $5961 \mathrm{~km}^{2}$ 'dir. Ordu ili 40¹9’70" Kuzey ve

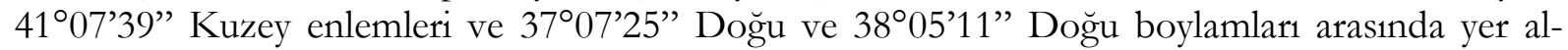
maktadır.

\section{Materyal ve Yöntem}

Çalışmaya ilk olarak literatür taramasıyla başlanmıştır. Sahaya uygun model belirlendikten sonra çalışma alanına ait harita üretimi için veriler ve kartografik malzemeler elde edilmiştir. Lokasyon haritası üretilirken ArcGIS 10.4 Coğrafi Bilgi Sistemleri yazılımı kullanılmıştır. Sonrasında modelin uygulanmasında gerekli arazi çalışmaları yapılarak gözlem ve incelemelerde bulunulmuştur. Bu esnada yerel halkla görüşülerek yine modelde kullanılabilecek bilgiler toplanmıştır. Ayrıca kaynak ve literatür taraması ile model desteklenmiştir.

Çalışmada kullanılan model Priskin (2001) tarafından geliştirilen "Doğa Temelli Turizm İçin Doğal Kaynakların Ölçümü (Assessment of Natural Resources for Nature-Based Tourism)" dür. Bu modelin temelleri 1999 yılında ortaya atılmış ve ilk doğa temelli turizm çalışması yapılmiştır (Weaver et al., 1999, p. 6). Modelde doğal turistik kaynaklar sınıflandırılmakta, peyzaj unsurları değerlendirilmekte, ulaşım olanakları ve turizm altyapısı incelenmektedir. Bunun sonucunda ise doğa temelli turizm açısından bir kaynak değerlendirmesi yapılmaktadır (Priskin, 2001, p. 637).

Modelin uygulanışı incelendiğinde ilk olarak veri toplama işlemi iki aşamalı şekilde gerçekleştirilmektedir (Priskin, 2001, p. 641). Birinci aşamada saha araştırması ile doğal turistik kaynaklar tanımlanmakta ve gözlemler yapılarak çeşitli bilgiler sahadan toplanmaktadır. İkinci aşamada ise literatür ve kaynak değerlendirmesi yapılmaktadır. Veri toplama işleminden sonra modelin içeriğindeki kriterler her bir turistik kaynağa uygulanarak sonuçlar yorumlanmaktadır (Priskin, 200, p. 641).

\subsection{Doğa Temelli Turizm İçin Doğaya Dayalı Turizm Olanaklarının Ölçüm Kri- terleri}

Çalışmada uygulanan modelde ölçümü yapılacak kriterler 4 ana kategori altında toplanmışt1r. Priskin (2001)'e göre bunlar:

1- Turistik çekicilik çeşitliliği,

2- Ulaşılabilirlik,

3- Destekleyici altyap1,

4- Çevresel bozulmadır.

\subsection{1. Ölçüm Kategorisi 1: Turistik Çekicilik Çeşitliliği}

Priskin (2001)'e göre kumlu bir plajın destinasyonun çekiciliğine olan katkısının, destinasyonu çevreleyen bir tepeden daha fazla olduğu düşüncesi her zaman özneldir. Bu kategori altında 10 ayrı gösterge ile her bir kaynak destinasyonun çekicilik çeşitliliğinin ortaya konulması amaçlanmıştır. Bunun için aşağıda yer alan her bir gösterge için turistik destinasyon 1-10 arası puan almaktadır. Örneğin bir destinasyon hem iyi kuma sahip bir plaja, hem de floral çeşitliliği yüksek bir alana sahip olabilir. Turistik çekiciliğe sahip destinasyonlar bu ölçüm kategorisi için en fazla 100 puan alabilmektedir (Priskin, 2001, p. 642). Priskin (2001)'e göre bu ölçüm kategorisi için göstergeler şunlardır:

1- Floral çeşitlilik (Vejetasyon özelliklerinin çeşitlilik seviyesi),

2- Peyzaj çeşitliliği (Peyzaj özelliklerinin çeşitlilik seviyesi), 
Hatipoğlu, Ş. C. (2021). Ordu ilinin doğaya dayalı turizm olanaklarının "doğa temelli turizm için doğal kaynakların ölçümü modeli” ile değerlendirilmesi, Mavi Atlas, 9(2), 92-107

3- Rekreasyon imkânları (Yüzme, yürüyüş, bisiklet sürmek, doğa yürüyüşü gibi rekreasyonel faaliyetler gerçekleştirme imkânı),

4- Macera imkânları (Arazide 4x4 araç kullanma, kum sörfü, planörle uçuş gibi riskli ve tehlikeli faaliyetler gerçekleştirme imkânı),

5- Koy ya da karasal su bölümü (Göl ya da burun tarafindan korunmuş kıyı çizgisi, sulak alan),

6- Kayalık kıyı çizgisi/falez (Kayalık çıkıntılar, burunlar, falezler, abrazyon platformlarının hâkim olduğu kıyı çizgisi),

7- Kumlu plaj (Düzgün kumlu plajların hâkim olduğu kıyı çizgisi),

8- İyi manzara (Daha geniş görüş açılı manzaranın görülebildiği yer),

9- Bilimsel açıdan ilginç (Kaya çıkıntıları, yerdeki derin delikler gibi sıra dışı özelliklere sahip bir alan ya da doğa rezervi gibi çok yüksek biyolojik çeşitliliğe sahip arazi kullanım süresi olan bir alan),

10- Jeolojik özellikler (Mağaralar, büyük kayalar, çıkıntılar, kireçtaşı sütunları).

Priskin (2001)'e göre nihai puanları yüksek olan destinasyonlar birden fazla ilgi çekici alana sahipken, düşük puana sahip destinasyonlar daha az sayıda çekici alana ve çeşitliliğe sahiptir. Elde edilen sonuçlara göre turistik destinasyonlar "düşük (0-33 puan)", "orta (34-66 puan)" ya da "yüksek (67-100 puan)" çeşitlilik şeklinde sınıflandırılırlar (Priskin, 2001, p. 642). Tüm bunlarla birlikte model içerisinde çeşitlilik türlerinin sayısal olarak dağılışını gösteren bir tablolama sistemi de bulunmaktadır. Bu tablolama sisteminde kıyısal çekicilikler, floral çekicilikler, jeolojik çekicilikler, göller ve piknik alanlarının toplam sayıları yer almaktadır (Priskin, 2001, p. 642).

\subsection{2. Ölçüm Kategorisi 2: Ulaşılabilirlik}

Ulaşımın kolaylı̆̆ı ya da zorluğu bir destinasyonun ziyaret edilmesinde öncelikli olarak göz önünde bulundurulan faktörlerden biridir. Ulaşılabilirlik kategorisi bu yöntemde iki gösterge ile ölçülmektedir. Bunlar "yol tipi” ve "araç sınıfi” göstergeleridir (Priskin, 2001, p. 642). Priskin (2001)'e göre yol tipi ve araç sınıfları "ulaşım yok/ya da sadece 4 çeker araç", "4 çeker araç/belki 2 çeker araç", "4 çeker araç, 2 çeker araç, minibüsle", "tüm araçlar/çakıllı yol” ve "tüm araçlar/asfalt yol" göstergelerine göre puanlanmaktadır. Uygulanacak ölçüm kategorisi sonucunda destinasyonlar "zayıf (1-2 puan)", "orta-zayıf (3-4 puan)", "orta (5-6 puan)", "Orta-iyi (7-8 puan)" ya da "iyi (9-10 puan)" ulaşılabilir olarak sınıflandırılırlar (Priskin, 2001, p. 642). Priskin (2001)'e göre göstergelerden her biri (araç sınıfı ve yol tipi) için turistik çekicilikler 0 ile 5 puan arasında bir değer almaktadır. Her bir çekiciliğin bu kategoride alabileceği en yüksek puan 10'dur. Örneğin bir destinasyona kumlu bir yoldan ulaşılabiliyorsa, o destinasyon yolunun kötü olması sebebiyle dört tekerden çekiş sistemine sahip bir araçla ancak ulaşım sağlanabileceğinden düşük puan alacaktır.

\subsection{3. Ölçüm Kategorisi 3: Destekleyici Altyapı}

Doğa temelli turizm için tesis olanakları son derece önemlidir. Öyle ki turistik yerdeki tesislerin eksikliği insanları bir yeri ziyaret etmekten vazgeçirebilir ya da tekrar ziyaret etmek istememesine neden olabilir (Priskin, 2001, p. 642). Priskin (2001)'e göre ziyaretçi altyapısının envanter haline getirilebilmesi için şu yedi gösterge kullanılmıstır:

1- Tuvalet tesisleri (Her türlü tuvalet, duş ve soyunma odaları dahil),

2- Piknik masaları (Yemek için oturaklı masalar),

3- Oturaklar/banklar (Basit park bankları gibi),

4- Barbekü (Ateş yakılabilecek yerler dahil pişirme tesisler),

5- Çöp kutuları (Her türlü atık bertaraf üniteleri, geri dönüşüm istasyonları),

6- Engelliler için erişim (Engelliler için tasarlanmış rampa vb. herhangi bir tesis), 
Hatipoğlu, Ş. C. (2021). Ordu ilinin doğaya dayalı turizm olanaklarının "doğa temelli turizm için doğal kaynakların ölçümü modeli” ile değerlendirilmesi, Mavi Atlas, 9(2), 92-107

7- Gölgelik/barınak (Çardaklar, barınaklar, saklanma alanları, ağaçlık alanlar gibi tesisler).

"Barınak" göstergesi dışındaki göstergeler 0 ya da 1 puan almaktadır (Priskin, 2001, p. 643). 0 puan bahsedilen göstergenin olmadığını temsil ederken 1 puan varlığını temsil etmektedir (Priskin, 2001, p. 643). Priskin (2001)'e göre "Barınak" göstergesinin önemini belirtmek için daha farklı bir değerlendirme ölçeği kullanılması gerekmektedir. Doğrudan iklimle alakalı olduğundan eğer barınak tesisi mevcutsa destinasyon 4 puan almakta iken turistik destinasyon doğal gölgelik vejetasyon örtüsüne sahipse 3 puan almaktadır. Her destinasyon bu ölçüm kategorisinden en fazla 10 puan alabilmektedir (Priskin, 2001, p. 643).

\subsection{4. Ölçüm Kategorisi 4: Çevresel Bozulma}

Çevresel kalite bir ekosistemin refahını ifade eder ve bunun yeterli bir değerlendirmesi ayrntilı bir bilimsel denetim ve derinlemesine analiz gerektirir (Priskin, 2001, p. 643). Priskin (2001)'e göre bu model deneyimlenmesi gereken bir kaynak olarak turizm ürünlerine odaklanmıştır. Bu sebeple modelde saha araştırmalarında fiziksel çevrenin ayrıntılı unsurları yerine çevresel bozulma seviyesine odaklanılmıştır. Bu yöntemde görsel olarak göze çarpan bozulma unsurları doğa temelli turistlerin keyfini kaçıracağından özellikle dikkate alınmaktadır (Priskin, 2001, p. 643). Priskin (2001) çevresel bozulma seviyesini değerlendirmek için şu 10 göstergenin kullanılması gerektiğini vurgulamıştır:

1- Çöp (Miktar, tip ve yoğunluk),

2- Yabani otlar (Yerli olmayan türlerin neden olduğu istila derecesi),

3- Hastalık (Geriye Doğru Ölüm (dieback) Hastalığı gibi ekosistemi etkileyen hastalıklar),

4- Yangının etkisi (Doğal olmayan olaylardan kaynaklanan, yani kamp, geçici ateşler),

5- Erozyon (Yolların erozyonu, ziyaretçilerin neden olduğu nehir kanalları),

6- Bitki örtüsünün ezilmesi (Fiziksel yapı bakımında vejetasyon sağlı̆̆ı),

7- Kumulların yok edilmesi (Kumulların turistlerden kaynaklanan kararsızlık derecesi),

8- Yeryüzü şekillerinin erozyonu (Doğal manzaranın sağlığı),

9- Yollar (Dört çeker araçların oluşturduğu amaç dişı yollar),

10- İnşa edilmiş yapılar (Gece kondular gibi turistik olmayan altyapı).

Priskin (2001)'e göre 10 göstergenin her birine 0 ile 10 arasında bir puan verilmektedir. Her turistik destinasyon bu kategori için en fazla 100 puan alabilmektedir. Düşük puan alan turistik destinasyonlar insanların neden olduğu bozulmanın en az olduğu alanları göstermektedir. $\mathrm{Bu}$ kategori için yüksek puan alan destinasyonlar rehabilitasyon/ ya da ziyaretçi yönetimi gerektiren alanlardır. Doğa ve vahşi ortam doğa temelli turizm için önemlidir. Bu nedenle destek altyapısı dışındaki beşerî yapılar turizm açısından olumsuzluk oluşturmaktadır (gece kondular gibi), (Priskin, 2001, p. 643).

\subsubsection{Doğal Turizm Kaynaklarının Bölgesel Önem Düzeyine Göre Ölçümü}

Tüm ölçüm kategorilerinin yanında sahadaki kaynakların çevredeki bölgelere kıyasla göreceli önemini belirlemek için turistik kaynak merkezinin coğrafi öneminin değerlendirilmesine de ihtiyaç duyulmuştur (Priskin, 2001, p. 645). Priskin (2001)'e göre kaynak merkezinin öneminin belirlenmesi, karar vericilerin kaynakları planlama ve yönetim çabalarını tahsis etmelerine yardımcı olabilir. Bu nedenle doğaya dayalı turizm kaynak merkezleri, önem düzeylerine göre dört kriter kullanılarak sınıflandırılmıştır (Priskin, 2001, p. 645). Priskin (2001)'e göre bunlar:

1- Kaynağın yerel olarak nadirliği,

2- Bölgesel veya ulusal ölçekte benzersizlik düzeyi,

3- Kaynağın çekim çeşitliliği derecesi, 
Hatipoğlu, Ş. C. (2021). Ordu ilinin doğaya dayalı turizm olanaklarının "doğa temelli turizm için doğal kaynakların ölçümü modeli” ile değerlendirilmesi, Mavi Atlas, 9(2), 92-107

4- Eğer varsa bir sonraki benzer kaynağa mesafedir.

Priskin (2001)'e göre her kritere 0'dan 10'a kadar sübjektif bir puan verilmiştir. En yüksek puan alan siteler en önemli cazibe merkezleridir. Bu ölçüm sonrasında kaynaklar "düşük", "orta" ve "yüksek" derecede öneme sahip olarak sınıflandırılsa da bu sınıflandırma bölgesel ölçektedir (Priskin, 2001, p. 645).

Priskin (2001)'e göre kaynakların korunması için doğal turizmde yönetim (belirli seviyede) gereklidir. Özellikle çevresel bozulma düzeyi sonuçları bu bağlamda çevre rehabilitasyonuna ihtiyaç duyan turizm merkezlerinin belirlenmesine yardımcı olur. Elde edilen diğer sonuçların da dikkate alınmasıyla beraber erişim ve destek altyapısı ihtiyacı olan turizm merkezlerinin belirlenmesi ve ziyaretçi yönetim tesislerinin kurulması önem arz etmektedir. Rehabilite edilecek merkezler aciliyet sırasına göre dizilerek gruplara ayrılabilir (Priskin, 2001, p. 645).

\section{Bulgular}

Doğa Temelli Turizm İçin Doğal Kaynakların Ölçümü Modeli, Ordu ili için uygulanırken ilçeler bazında değerlendirmeler yapılması daha uygun görülmüştür. Çünkü ilçelerdeki turistik kaynakların tek tek ele alınması durumunda yöntem kriterlerinin tam olarak uygulanması pek mümkün olmamaktadır. Çünkü çoğunlukla turistik kaynaklar tek bir çeşitliliğe sahiptir. Bu sebeple ilçeler birer turizm kaynağı olarak ele alınmış ve bu sayede her ilçedeki turizm çeşitliliği daha rahat ortaya koyulabilmiştir. Ayrıca uygulanan yönteme çalışma sahasına uygun olacak şekilde bazı eklemeler de yapılmıştır. Doğaya dayalı kaynak türlerinin geniş sınıflandırması kısmında "şelale" ve "diğer" kriterleri tarafimızca eklenmiştir. Bunun sebebi ise Ordu'da çok sayıda şelale bulunması ve bu kategorilerden hiçbirine girmeyen doğal turistik kaynakların da (kaplica vb.) mevcut olmas1dır. Ayrıca ulaşım kısmına "bozuk asfaltlı yol" değeri tarafımızca eklenmiştir. Bunun sebebi tüm ilçe yollarının asfalta sahip olması yanında bazı ilçelerde asfalt yapısının bozuk olmasıdır.

\section{1. Ölçüm Kategorisi 1: Çekicilik Çeşitliliği}

Saha çalışmaları ve literatür taraması sonucu yapılan değerlendirmeye göre ilk kategori olan çekicilik çeşitliliğine ait sonuçlar tablo hâline getirilmiştir (Tablo 1). Ayrıca hangi ilçenin hangi seviyedeki çeşitlilik sınıfına girdiği de yine tablo halinde verilmiştir (Tablo 2). Tablo 1 incelendiğinde çekicilik çeşitliliği bakımından en yüksek puana sahip ilçe Perşembe, en düşük puana sahip ilçe ise Kabataş olmuştur. Bu değerlendirmeye göre Perşembe ilçesi çekicilik çeşitliliği bakımından yüksek çeşitliliğe sahip iken Altınordu, Fatsa, Ünye, Gülyalı, Kabadüz, Akkuş, Kumru, Korgan, Çamaş, Gölköy, Ulubey, Mesudiye ve Aybastı ilçeleri orta düzeyde çeşitliliğge sahiptir. Çaybaş1, İkizce, Çatalpınar, Kabataş ve Gürgentepe ilçeleri ise düşük çeşitliliğe sahip ilçelerdir. Tablo 2 incelendiğinde düşük çekicilik sınıfına gire 5 ilçe bulunurken bunun ildeki yüzdesi $\% 26,3$, orta çeşitlilik sınıfına giren ilçe sayısı 13 ve ildeki yüzdesi \%68,4, yüksek çeşitlilik sınıfına giren ilçe sayıs1 1 ve ildeki yüzdesi ise $\% 5,3$ 'tür.

Yöntemde bulunan çekicilik çeşitliliği türlerinin sayı bazında gösterildiği bir tablolama sistemi de Ordu ili ilçeleri için uygulanmıştır (Tablo 3). Bu bölümde "floral" çeşitlilik türü kısmında doğal bitki örtüsü baz alınmamış yalnızca anıt ağaçlar hesaplamaya katılmıştır. Aksi hâlde bitki örtüsünün adet olarak hesaplanması mümkün değildir. Bitki örtüsü çeşitliliği ile ilgili puanlama önceki bölümde "Floral Çeşitlilik" kısmında zaten yapılmıștır. Tablo 3'e göre çeşitliliklerin sayısı bakımından en yüksek puana sahip ilçe "34" puanla Altınordu ilçesidir. Altınordu ilçesi için çeşitlilik türü olarak "floral" ve "şelale" doğal turistik kaynaklar hâkimdir. "Floral" türünün bu kadar yüksek puanda olmasının sebebi ise ilçede çok sayıda anıt ağacın bulunmasıdır. En düşük çeşitlilik sayısı puanına sahip olan ilçe ise Kabataş’tır. Kabataş ilçesi bu çeşitlilik türlerinin hiçbirine sahip olmadığından " 0 ” puan almıştır. 
Hatipoğlu, Ş. C. (2021). Ordu ilinin doğaya dayalı turizm olanaklarının "doğa temelli turizm için doğal kaynakların ölçümü modeli” ile değerlendirilmesi, Mavi Atlas, 9(2), 92-107

Tablo 1. Çekicilik çeşitliliği kategorisine ait göstergelerin ilçe bazında değerlendirmesi.

\begin{tabular}{|c|c|c|c|c|c|c|c|c|c|c|c|}
\hline & $\begin{array}{c}\text { Floral } \\
\text { Çeşitli- } \\
\text { lik }\end{array}$ & $\begin{array}{c}\text { Peyzaj } \\
\text { Çeşitli- } \\
\text { liği }\end{array}$ & $\begin{array}{l}\text { Rekreas- } \\
\text { yon } \\
\text { İmkanları }\end{array}$ & $\begin{array}{c}\text { Macera } \\
\text { İmkan- } \\
\text { lar1 }\end{array}$ & $\begin{array}{l}\text { Koy ya da } \\
\text { iç kesim- } \\
\text { lerdeki su } \\
\text { kütlesi }\end{array}$ & $\begin{array}{c}\text { Kayalık } \\
\text { k1y1 } \\
\text { seri- } \\
\text { di/falez } \\
\end{array}$ & $\begin{array}{l}\text { Kum- } \\
\text { lu plaj }\end{array}$ & $\begin{array}{c}\text { İyi } \\
\text { manza- } \\
\text { ra }\end{array}$ & $\begin{array}{l}\text { Bilim- } \\
\text { sel } \\
\text { açıdan } \\
\text { ilginç } \\
\end{array}$ & $\begin{array}{l}\text { Jeolojik } \\
\text { özellik- } \\
\text { ler }\end{array}$ & $\begin{array}{l}\text { Top- } \\
\text { lam }\end{array}$ \\
\hline Altınordu & 8 & 9 & 8 & 7 & 2 & 0 & 8 & 8 & 3 & 5 & 58 \\
\hline Fatsa & 7 & 8 & 7 & 3 & 5 & 0 & 8 & 8 & 4 & 5 & 55 \\
\hline Ünye & 7 & 9 & 8 & 3 & 2 & 0 & 9 & 8 & 4 & 7 & 57 \\
\hline Gülyalı & 6 & 7 & 7 & 0 & 1 & 0 & 6 & 7 & 0 & 0 & 34 \\
\hline Çaybaşı & 6 & 6 & 7 & 2 & 0 & 0 & 0 & 6 & 0 & 0 & 27 \\
\hline İkizce & 5 & 6 & 6 & 2 & 0 & 0 & 0 & 6 & 0 & 0 & 25 \\
\hline Kabadüz & 9 & 8 & 10 & 6 & 0 & 0 & 0 & 10 & 7 & 6 & 56 \\
\hline Perşembe & 8 & 7 & 8 & 3 & 8 & 10 & 7 & 10 & 7 & 7 & 75 \\
\hline Akkuş & 9 & 6 & 7 & 4 & 0 & 0 & 0 & 8 & 6 & 2 & 42 \\
\hline Kumru & 7 & 6 & 5 & 3 & 0 & 0 & 0 & 7 & 5 & 2 & 35 \\
\hline Korgan & 8 & 6 & 6 & 3 & 3 & 0 & 0 & 8 & 5 & 2 & 41 \\
\hline Çatalpınar & 7 & 5 & 3 & 0 & 0 & 0 & 0 & 5 & 3 & 2 & 25 \\
\hline Çamaş & 8 & 6 & 7 & 3 & 0 & 0 & 0 & 8 & 5 & 4 & 41 \\
\hline Kabataş & 7 & 4 & 3 & 0 & 0 & 0 & 0 & 4 & 2 & 0 & 20 \\
\hline $\begin{array}{l}\text { Gürgente- } \\
\text { pe }\end{array}$ & 7 & 5 & 5 & 0 & 0 & 0 & 0 & 6 & 2 & 6 & 31 \\
\hline Gölköy & 8 & 7 & 8 & 3 & 5 & 0 & 0 & 9 & 6 & 2 & 48 \\
\hline Ulubey & 8 & 6 & 7 & 4 & 0 & 0 & 0 & 7 & 6 & 5 & 42 \\
\hline Mesudiye & 8 & 7 & 8 & 3 & 5 & 0 & 0 & 8 & 6 & 5 & 50 \\
\hline Aybast1 & 9 & 9 & 10 & 6 & 0 & 0 & 0 & 10 & 6 & 5 & 55 \\
\hline
\end{tabular}

Tablo 2. İlçelere ait çeşitlilik sınıfları ve il bazındaki yüzdeleri.

\begin{tabular}{|c|c|c|c|}
\hline Çekicilik Sınıfi & Değerler & İlçe Sayı1s1 & İldeki \% \\
\hline Düsük Çeşitlilik & $0-33$ & 5 & 26,3 \\
\hline Orta Çeşitlilik & $34-66$ & 13 & 68,4 \\
\hline Yüksek Çeşitlilik & $67-100$ & 1 & 5,3 \\
\hline Toplam & - & 19 & 100 \\
\hline
\end{tabular}

Tablo 3. Doğaya dayalı kaynak türlerin geniş bir sınıflandırılması ve sayıları.

\begin{tabular}{|c|c|c|c|c|c|c|c|c|}
\hline & Kiyısal & Floral & Jeolojik & Göl & Piknik Alanı & Şelale* & Diğer* & Toplam \\
\hline Altınordu & 3 & 21 & 1 & 0 & 3 & 6 & 0 & 34 \\
\hline Fatsa & 3 & 5 & 3 & 1 & 0 & 6 & 1 & 19 \\
\hline Ünye & 6 & 1 & 5 & 1 & 5 & 3 & 0 & 21 \\
\hline Gülyalı & 4 & 0 & 0 & 0 & 0 & 0 & 0 & 4 \\
\hline Çaybaşı & 0 & 0 & 0 & 0 & 1 & 4 & 0 & 5 \\
\hline İkizce & 0 & 0 & 0 & 0 & 0 & 2 & 0 & 2 \\
\hline Kabadüz & 0 & 0 & 4 & 0 & 3 & 4 & 0 & 11 \\
\hline Perşembe & 6 & 4 & 1 & 0 & 1 & 4 & 0 & 16 \\
\hline Akkuş & 0 & 2 & 0 & 0 & 2 & 3 & 0 & 7 \\
\hline Kumru & 0 & 0 & 4 & 0 & 1 & 3 & 0 & 8 \\
\hline Korgan & 0 & 0 & 0 & 1 & 3 & 7 & 0 & 11 \\
\hline Çatalpinar & 0 & 1 & 0 & 0 & 0 & 1 & 0 & 2 \\
\hline Çamaş & 0 & 0 & 1 & 0 & 2 & 3 & 0 & 6 \\
\hline Kabataş & 0 & 0 & 0 & 0 & 0 & 0 & 0 & 0 \\
\hline Gürgentepe & 0 & 0 & 0 & 0 & 0 & 1 & 0 & 1 \\
\hline Gölköy & 0 & 11 & 0 & 3 & 2 & 5 & 0 & 21 \\
\hline Ulubey & 0 & 0 & 1 & 0 & 1 & 3 & 0 & 5 \\
\hline Mesudiye & 0 & 0 & 2 & 3 & 8 & 2 & 0 & 15 \\
\hline Aybastı & 0 & 0 & 0 & 0 & 4 & 3 & 0 & 7 \\
\hline
\end{tabular}

*Bu kriter tarafımızca yönteme eklenmiştir. 
Hatipoğlu, Ş. C. (2021). Ordu ilinin doğaya dayalı turizm olanaklarının "doğa temelli turizm için doğal kaynakların ölçümü modeli” ile değerlendirilmesi, Mavi Atlas, 9(2), 92-107

\section{2. Ölçüm Kategorisi 2: Ulaş1labilirlik}

Ulaşılabilirlik kategorisinde bulunan 2 göstergeye (yol tipi ve araç sınıfi) göre Ordu ili ilçeleri değerlendirmeye tutulmuş ve tablo hâlinde sunulmuştur (Tablo 4). Ayrıca modelde yer alan bir tablo daha oluşturulmuş ve erişim sınıflarının ildeki yüzdesi gösterilmiştir (Tablo 5). Tablo 4 incelendiğinde Çaybaşı, İkizce, Akkuş, Kumru, Korgan, Çatalpınar, Kabataş ve Aybastı'nın 8'er puan alarak orta-iyi erişim sınıfına girdiği, Kabadüz, Çamaş, Gürgentepe, Gölköy ve Ulubey ilçelerinin 9 puan ve Altınordu, Fatsa, Ünye, Gülyalı ve Mesudiye ilçelerinin ise 10 puan alarak iyi erişim sınıfina girdiği görülmüştür (Tablo 4). Tablo 5 incelendiğinde orta-iyi ulaşım sınıfina giren 8 ilçe bulunurken bunların ildeki yüzdesi \%42,1'dir. İyi ulaşım sınıfına giren 11 ilçe bulunmakta ve bunların ildeki yüzdesi ise \%57,9’tür (Tablo 5).

Tablo 4. Ulaşılabilirlik kategorisine göre kaynakların sınıflandırılması.

\begin{tabular}{|c|c|c|c|}
\hline & Yol Tipi & Araç Sınıfi & Toplam \\
\hline Altınordu & 5 & 5 & 10 \\
\hline Fatsa & 5 & 5 & 10 \\
\hline Ünye & 5 & 5 & 10 \\
\hline Gülyalı & 5 & 5 & 8 \\
\hline Çaybaşı & 3 & 5 & 8 \\
\hline İkizce & 3 & 5 & 10 \\
\hline Kabadüz & 4 & 5 & 8 \\
\hline Perşembe & 5 & 5 & 8 \\
\hline Akkuş & 3 & 5 & 8 \\
\hline Kumru & 3 & 5 & 8 \\
\hline Korgan & 3 & 5 & 8 \\
\hline Çatalpınar & 3 & 5 & 9 \\
\hline Çamaş & 4 & 5 & 9 \\
\hline Kabataş & 3 & 5 & 9 \\
\hline Gürgentepe & 4 & 5 & 10 \\
\hline Gölköy & 4 & 5 & 8 \\
\hline Ulubey & 4 & 5 & \\
\hline Mesudiye & 5 & 5 & \\
\hline Aybastı & 3 & & \\
\hline
\end{tabular}

Tablo 5. İlçelere ait ulaşım sınıfları ve il bazında yüzdeleri.

\begin{tabular}{|c|c|c|c|}
\hline Ulaşım Sınıfları & Değerler & İlçe sayısı & İldeki \% \\
\hline Zayıf (1-2) & Ulaşım yok/ya da sadece 4 çeker araç & 0 & 0 \\
\hline Orta-zayıf (3-4) & 4 çeker araç/belki 2 çeker araç & 0 & 0 \\
\hline Orta (5-6) & 4 çeker araç, 2 çeker araç, minibüsle & 0 & 0 \\
\hline Orta-iyi (7-8) & Tüm araçlar/çakııllı yol/bozuk asfaltlı yol* & 8 & 42,1 \\
\hline İyi (9-10) & Tüm araçlar/asfalt yol & 11 & 57,9 \\
\hline Toplam & - & 19 & 100 \\
\hline
\end{tabular}

*Bu kriter tarafımızca yönteme eklenmiştir.

\section{3. Ölçüm Kategorisi 3: Destekleyici Altyap1}

Destekleyici altyapı kategorisinde Ordu ili ilçeleri 7 gösterge üzerinden değerlendirilmiş ve sonuçlar tablo hâline getirilmiştir (Tablo 6). Tablo 6 incelendiğinde Altınordu, Fatsa ve Ünye ilçeleri 10'ar puan alırken Perşembe, Gülyalı, Gölköy ve Kabadüz ilçeleri 9'ar puan almıştır. Aybastı, Ulubey ve Mesudiye 8'er puan alırken Akkuş, Çamaş, Gürgentepe ve 7'şer puan almıştır. Kumru, Korgan, Çaybaşı ve İkizce ilçeleri bu kategoriden 6'şar puan alırken, Çatalpınar ve Kabataş ilçeleri ise 5'er puana sahiptir. 
Hatipoğlu, Ş. C. (2021). Ordu ilinin doğaya dayalı turizm olanaklarının "doğa temelli turizm için doğal kaynakların ölçümü modeli” ile değerlendirilmesi, Mavi Atlas, 9(2), 92-107

Tablo 6. Destekleyici altyapı kategorisine ait göstergelerin ilçe bazında değerlendirmesi.

\begin{tabular}{|c|c|c|c|c|c|c|c|c|}
\hline & $\begin{array}{c}\text { Tuvalet } \\
\text { Tesisleri }\end{array}$ & $\begin{array}{c}\text { Piknik } \\
\text { Masaları }\end{array}$ & Oturaklar/Banklar & Barbekü & Çöp Kutuları & $\begin{array}{c}\text { Engelliler İçin } \\
\text { Erişim }\end{array}$ & $\begin{array}{c}\text { Koruma } \\
\text { Barınak }\end{array}$ & Toplam \\
\hline Altınordu & 1 & 1 & 1 & 1 & 1 & 1 & 4 & 10 \\
\hline Fatsa & 1 & 1 & 1 & 1 & 1 & 1 & 4 & 10 \\
\hline Ünye & 1 & 1 & 1 & 1 & 1 & 1 & 4 & 10 \\
\hline Gülyalı & 1 & 1 & 1 & 0 & 1 & 1 & 4 & 9 \\
\hline Çaybaşı & 1 & 0 & 1 & 0 & 1 & 0 & 3 & 6 \\
\hline İkizce & 1 & 0 & 1 & 0 & 1 & 0 & 3 & 6 \\
\hline Kabadüz & 1 & 1 & 1 & 1 & 1 & 0 & 4 & 9 \\
\hline Perşembe & 1 & 1 & 1 & 1 & 1 & 1 & 3 & 9 \\
\hline Akkuş & 1 & 0 & 1 & 1 & 1 & 0 & 3 & 7 \\
\hline Kumru & 1 & 0 & 1 & 0 & 1 & 0 & 3 & 6 \\
\hline Korgan & 1 & 0 & 1 & 0 & 1 & 0 & 3 & 6 \\
\hline Çatalpınar & 1 & 0 & 0 & 0 & 1 & 0 & 3 & 5 \\
\hline Çamaş & 1 & 1 & 1 & 0 & 1 & 0 & 3 & 7 \\
\hline Kabataş & 1 & 0 & 0 & 0 & 1 & 0 & 3 & 5 \\
\hline Gürgentepe & 1 & 1 & 1 & 0 & 1 & 0 & 3 & 7 \\
\hline Gölköy & 1 & 1 & 1 & 1 & 1 & 0 & 4 & 9 \\
\hline Ulubey & 1 & 1 & 1 & 1 & 1 & 0 & 3 & 8 \\
\hline Mesudiye & 1 & 1 & 1 & 1 & 1 & 0 & 3 & 3 \\
\hline Aybastı & 1 & 1 & 1 & 1 & 1 & 0 & 3 & 8 \\
\hline
\end{tabular}

\section{4. Ölçüm Kategorisi 4: Çevresel Bozulma}

Çevresel bozulma kategorisi altında Ordu ili ilçeleri 10 gösterge üzerinden değerlendirmeye alınmış ve sonuçlar tablo şeklinde sunulmuştur (Tablo 7). Tablo 8'de ise ilçelerin dahil olduğu bozulma seviyesi sınıfları gösterilmiştir (Tablo 8). Tablo 7 incelendiğinde Altınordu, Fatsa, Ünye, Gülyalı, Perşembe, İkizce, Korgan, Kumru, Aybastı, Akkuş, Mesudiye, Gölköy, Gürgentepe, Çamaş, Kabataş, Çatalpınar ve Ulubey ilçeleri göstergelerden aldıkları puanlarla düşük çevresel bozulma sınıfına dâhil olmuşlardır. Bu bakımdan koruma tedbirlerinin yeterli olduğu söylenebilir. Ancak Çaybaşı ve Kabadüz aldıkları puanlar doğrultusunda düşük-orta düzeyde çevresel bozulma sınıfindadır. Bu noktada çok yüksek oranda olmamakla birlikte Çaybaşı ve Kabadüz'de çevresel bozulmanın yaşandığı söylenebilir. 
Hatipoğlu, Ş. C. (2021). Ordu ilinin doğaya dayalı turizm olanaklarının "doğa temelli turizm için doğal kaynakların ölçümü modeli” ile değerlendirilmesi, Mavi Atlas, 9(2), 92-107

Tablo 7. Çevresel bozulma kategorisine ait göstergelerin ilçe bazında değerlendirilmesi.

\begin{tabular}{|c|c|c|c|c|c|c|c|c|c|c|c|}
\hline & Çöp & $\begin{array}{c}\text { Yabani } \\
\text { Otlar }\end{array}$ & Hastalık & $\begin{array}{c}\text { Yangının } \\
\text { Etkisi }\end{array}$ & Erozyon & $\begin{array}{c}\text { Bitkilerin } \\
\text { Ezilmesi }\end{array}$ & $\begin{array}{c}\text { Kumulların } \\
\text { Yok Edil- } \\
\text { mesi }\end{array}$ & $\begin{array}{c}\text { Yeryüzü } \\
\text { Sekillerinin } \\
\text { Erozyonu }\end{array}$ & Yollar & $\begin{array}{c}\text { Inşa } \\
\text { Edilmiş } \\
\text { Yapırlar }\end{array}$ & Toplam \\
\hline Altınordu & 3 & 2 & 0 & 0 & 4 & 1 & 1 & 2 & 1 & 4 & 18 \\
\hline Fatsa & 2 & 3 & 0 & 0 & 4 & 3 & 1 & 4 & 0 & 3 & 20 \\
\hline Ünye & 2 & 2 & 0 & 0 & 3 & 2 & 1 & 2 & 0 & 4 & 16 \\
\hline Gülyalı & 0 & 3 & 0 & 0 & 3 & 2 & 2 & 3 & 0 & 2 & 15 \\
\hline Çaybaşı & 8 & 3 & 0 & 0 & 5 & 0 & 0 & 1 & 2 & 2 & 21 \\
\hline Ikizce & 2 & 3 & 0 & 0 & 5 & 0 & 0 & 2 & 1 & 2 & 15 \\
\hline Kabadüz & 0 & 3 & 0 & 0 & 5 & 3 & 0 & 3 & 3 & 4 & 21 \\
\hline Perşembe & 3 & 2 & 0 & 0 & 3 & 1 & 2 & 1 & 0 & 3 & 15 \\
\hline Akkuş & 0 & 4 & 0 & 0 & 5 & 0 & 0 & 0 & 2 & 2 & 13 \\
\hline Kumru & 0 & 3 & 0 & 0 & 5 & 1 & 0 & 1 & 0 & 1 & 11 \\
\hline Korgan & 0 & 3 & 0 & 0 & 7 & 1 & 0 & 2 & 1 & 2 & 16 \\
\hline Çatalpınar & 0 & 3 & 0 & 0 & 5 & 1 & 0 & 1 & 0 & 1 & 11 \\
\hline Çamaş & 0 & 3 & 0 & 0 & 4 & 1 & 0 & 1 & 1 & 2 & 12 \\
\hline Kabataş & 0 & 2 & 0 & 0 & 4 & 1 & 0 & 1 & 0 & 1 & 9 \\
\hline Gürgentepe & 0 & 3 & 0 & 0 & 4 & 1 & 0 & 1 & 0 & 1 & 10 \\
\hline Gölköy & 0 & 2 & 0 & 0 & 5 & 1 & 0 & 3 & 1 & 2 & 14 \\
\hline Ulubey & 0 & 3 & 0 & 0 & 4 & 1 & 0 & 2 & 0 & 2 & 12 \\
\hline Mesudiye & 0 & 3 & 0 & 0 & 5 & 0 & 0 & 2 & 2 & 3 & 15 \\
\hline Aybastı & 0 & 3 & 0 & 0 & 5 & 0 & 0 & 2 & 5 & 2 & 17 \\
\hline
\end{tabular}

Tablo 8. İlçelere ait bozulma seviyesi ve il bazında yüzdeleri.

\begin{tabular}{|c|c|c|c|}
\hline Bozulma Seviyesi & Değerler & İlçe sayısı & İldeki \% \\
\hline Düşük & $0-20$ & 17 & 89,5 \\
\hline Düşük-orta & $21-40$ & 2 & 10,5 \\
\hline Orta & $41-60$ & - & - \\
\hline Orta-yüksek & $61-80$ & - & - \\
\hline Yüksek & $81-100$ & - & 100 \\
\hline Toplam & - & 19 & \\
\hline
\end{tabular}

\subsection{Ordu İli Doğal Turizm Kaynaklarının Bölgesel Önem Düzeyi Ölçümü}

Doğal turizm kaynaklarının bölgesel önem düzeyine göre ölçüm kategorisinde bulunan 4 alt gösterge üzerinden Ordu ili ilçeler bazında değerlendirilmiş ve elde edilen sonuçlar tablolar halinde sunulmuştur (Tablo 9), (Tablo 10), (Tablo 11). Tablolar incelendiğinde göstergelerden en yüksek puanı alan Aybastı ve Kabadüz ilçeleri, doğaya dayalı turizm bakımından en önemli turistik kaynak sahaları olarak dikkati çekerken bu ilçeleri takip eden Altınordu, Perşembe ve Mesudiye ilçelerinin de yine önemli turistik kaynak sahaları olduğu görülmektedir. Fatsa, Ünye, Gülyalı, Akkuş, Kumru, Korgan, Çamaş, Gürgentepe, Gölköy ve Ulubey ise aldıkları puanlara göre önem düzeyi orta seviye olan kaynak sahaları olmuştur. En düşük puanı alan İkizce, Çaybaşı, Kabataş ve Çatalpınar ilçeleri ise önem düzeyi en düşük turistik kaynak sahaları olmuştur. Bu alanların turizm çekicilik düzenin artırılması için bir dizi önlemlerin alınması gerekmektedir. Bu konuda sonuç kısmında önerilerde bulunulmuştur.

Tablo 9. İlçelerin önem düzeylerine göre değerlendirilmesi.

\begin{tabular}{|c|c|c|c|c|c|c|c|}
\hline & Altınordu & Fatsa & Ünye & Gülyalı & Çaybaşı & İkizce & Kabadüz \\
\hline Kaynağın yerel alanda nadir olması & 8 & 5 & 6 & 3 & 3 & 3 & 9 \\
\hline Bölgesel ve ulusal ölçekte benzersizlik düzeyi & 5 & 4 & 4 & 4 & 2 & 3 & 8 \\
\hline Kaynağın çekim çeşitlilik derecesi & 9 & 7 & 7 & 4 & 5 & 3 & 7 \\
\hline $\begin{array}{c}\text { Eğer varsa yakın benzer özellikteki kaynağa olan } \\
\text { mesafe }\end{array}$ & 5 & 5 & 5 & 3 & 3 & 3 & 5 \\
\hline Toplam & 27 & 21 & 22 & 14 & 13 & 12 & 29 \\
\hline
\end{tabular}


Hatipoğlu, Ş. C. (2021). Ordu ilinin doğaya dayalı turizm olanaklarının "doğa temelli turizm için doğal kaynakların ölçümü modeli” ile değerlendirilmesi, Mavi Atlas, 9(2), 92-107

Tablo 10. İlçelerin önem düzeylerine göre değerlendirilmesi-2.

\begin{tabular}{|c|c|c|c|c|c|c|}
\hline & Perşembe & Akkuş & Kumru & Korgan & Çatalpınar & Çamaş \\
\hline Kaynağın yerel alanda nadir olmas1 & 7 & 6 & 3 & 5 & 3 & 5 \\
\hline Bölgesel ve ulusal ölçekte benzersizlik düzeyi & 5 & 5 & 4 & 4 & 3 & 4 \\
\hline Kaynağın çekim çeşitlilik derecesi & 8 & 4 & 4 & 6 & 3 & 6 \\
\hline Eğer varsa yakın benzer özellikteki kaynağa olan mesafe & 5 & 4 & 4 & 4 & 4 & 4 \\
\hline Toplam & 25 & 19 & 15 & 19 & 13 & 19 \\
\hline
\end{tabular}

Tablo 11. İlçelerin önem düzeylerine göre değerlendirilmesi-3.

\begin{tabular}{|c|c|c|c|c|c|c|}
\hline & Kabataş & Gürgentepe & Gölköy & Ulubey & Mesudiye & Aybast1 \\
\hline Kaynağın yerel alanda nadir olmas1 & 3 & 4 & 7 & 5 & 7 & 9 \\
\hline Bölgesel ve ulusal ölçekte benzersizlik düzeyi & 4 & 3 & 5 & 4 & 7 & 8 \\
\hline Kaynağın çekim çeşitlilik derecesi & 3 & 4 & 7 & 5 & 7 & 7 \\
\hline Eğer varsa yakın benzer özellikteki kaynağa olan mesafe & 3 & 4 & 5 & 4 & 5 & 5 \\
\hline Toplam & 13 & 15 & 24 & 18 & 26 & 29 \\
\hline
\end{tabular}

\section{Sonuç ve Öneriler}

Çalışmada Ordu ilinin doğaya dayalı turizm olanaklarının değerlendirmenin yanında mevcut ve tespit edilebilecek eksikliklere yönelik öneriler getirmek amaçlanmıştır. Bu bağlamda çalışmada Ordu ilindeki doğa temelli turizm olanakları Priskin (2001) tarafindan geliştirilen "Doğa Temelli Turizm İçin Doğal Kaynakların Ölçümü (Assessment of Natural Resources for Naturebased Tourism) modeli ile değerlendirilmiştir.

Ordu ili ilçeleri için uygulanan "Doğa Temelli Turizm İçin Doğal Kaynakların Ölçümü” modeli sonuçlarına göre çekicilik çeşitliliği bakımından en yüksek ilçe Perşembe, en düşük ilçe ise Kabataş olmuştur. Bu değerlendirmeye göre Perşembe ilçesi çekicilik çeşitliliği bakımından yüksek çeşitliliğe sahip iken Altınordu, Fatsa, Ünye, Gülyalı, Kabadüz, Akkuş, Kumru, Korgan, Çamaş, Gölköy, Ulubey, Mesudiye ve Aybastı ilçeleri orta düzeyde çeşitliliğge sahiptir. Çaybaşı, İkizce, Çatalpınar, Kabataş ve Gürgentepe ilçeleri ise düşük çeşitliliğe sahip ilçelerdir. Yöntemde bulunan çekicilik çeşitliliklerin adedi bakımından en yüksek puana sahip ilçe "34" puanla Altınordu ilçesidir. Altınordu ilçesi için çeşitlilik türü olarak "floral" ve "şelale" doğal turistik kaynaklar hâkimdir. "Floral" türünün bu kadar yüksek puanda olmasının sebebi ise ilçede çok sayıda anıt ağacın bulunmasıdır. En düşük çeşitlilik sayısı puanına sahip olan ilçe ise Kabataş'tır. Kabataş ilçesi bu çeşitlilik türlerinin hiçbirine sahip olmadığından " 0 " puan almıştır. Ulaşılabilirlik kategorisi bakımından Çaybaşı, İkizce, Akkuş, Kumru, Korgan, Çatalpınar, Kabataş ve Aybastı'nın 8'er puan alarak orta-iyi erişim sınıfina girdiği, Kabadüz, Çamaş, Gürgentepe, Gölköy ve Ulubey ilçelerinin 9 puan ve Altınordu, Fatsa, Ünye, Gülyalı ve Mesudiye ilçelerinin ise 10 puan alarak iyi erişim sınıfina girdiği görülmüştür. Destekleyici altyapı kategorisinde Altınordu, Fatsa ve Ünye ilçeleri 10'ar puan alırken Perşembe, Gülyalı, Gölköy ve Kabadüz ilçeleri 9'ar puan almıştır. Aybastı, Ulubey ve Mesudiye 8'er puan alırken Akkuş, Çamaş, Gürgentepe ve 7'şer puan almıştır. Kumru, Korgan, Çaybaşı ve İkizce ilçeleri bu kategoriden 6'şar puan alırken, Çatalpınar ve Kabataş ilçeleri ise 5'er puana sahiptir. Çevresel bozulma kategorisinde Altınordu, Fatsa, Ünye, Gülyalı, Perşembe, İkizce, Korgan, Kumru, Aybastı, Akkuş, Mesudiye, Gölköy, Gürgentepe, Çamaş, Kabataş, Çatalpınar ve Ulubey ilçeleri göstergelerden aldıkları puanlarla düşük çevresel bozulma sınıfına dâhil olmuşlardır. Ancak Çaybaşı ve Kabadüz aldıkları puanlar doğrultusunda düşük-orta düzeyde çevresel bozulma sınıfındadır. Bu noktada çok yüksek oranda olmamakla birlikte Çaybaşı ve Kabadüz'de çevresel bozulmanın yaşandığı söylenebilir. Doğal turizm kaynaklarının bölgesel önem düzeyine göre ölçüm kategorisinde göstergelerden en yüksek puanı alan Aybastı ve Kabadüz ilçeleri doğaya dayalı turizm bakımından en önemli turistik kaynak sahaları olarak dikkati çekerken bu ilçeleri takip eden Altınordu, Perşembe ve Mesudiye ilçelerinin de yine önemli turistik kaynak sahaları olduğu görülmektedir. Fatsa, Ünye, Gülyalı, Akkuş, Kumru, Korgan, Çamaş, Gürgentepe, Gölköy ve Ulubey ise aldıkları puanlara göre önem düzeyi orta seviye olan kaynak sahaları olmuştur. En 
Hatipoğlu, Ş. C. (2021). Ordu ilinin doğaya dayalı turizm olanaklarının "doğa temelli turizm için doğal kaynakların ölçümü modeli” ile değerlendirilmesi, Mavi Atlas, 9(2), 92-107

düşük puanı alan İkizce, Çaybaşı, Kabataş ve Çatalpınar ilçeleri ise önem düzeyi en düşük turistik kaynak sahaları olmuştur.

\subsection{Doğa Temelli Turizm Bakımından Ordu İli İçin Öneriler}

Çalışma sahasına uygulanan model sonucu elde edilen bulgulara yönelik birtakım öneriler sunulmuştur. Bu öneriler her bir ölçüm kategorisi için ayrı ayrı ele alınmıştır.

\subsection{1. Çekicilik Çeşitliliği ile İlgili Öneriler}

Çekicilik çeşitliliği kategorisi değerlendirmesi sonucu Çaybaşı, İkizce, Çatalpınar, Kabataş ve Gürgentepe ilçeleri düşük çeşitliliğe sahip ilçeler olduğu görülmektedir. Bu nedenle yalnız başlarına bu ilçeler turistik açıdan yeterince dikkat çekici olmayabilir. Coğrafi konum olarak da birbirlerine çok yakın olan Çaybaşı ve İkizce ilçeleri ile Çatalpınar ve Kabataş ilçeleri turizm açısından birlikte değerlendirilebilir. Örneğin tur planlaması yapılırken güzergâh hem Çaybaşı hem de İkizce ilçelerini kapsayacak şekilde oluşturulabilir. Aynı şekilde Çatalpınar ve Kabataş ilçelerinin ikisini birden kapsayan rotalar oluşturulabilir. Yine Gürgentepe ilçesi orta düzeyde çekiciliğe sahip Gölköy ilçesi için oluşturulabilecek güzergâhların içerisine dâhil edilerek turizme kazandırılabilir. $\mathrm{Bu}$ sayede turistlerin yöreyi ziyaret etmek için vereceği karar sürecine olumlu bir etki yapılabilir. Orta düzeyde çeşitliliğe sahip Altınordu, Fatsa, Ünye, Gülyalı, Kabadüz, Akkuş, Kumru, Korgan, Çamaş, Gölköy, Ulubey, Mesudiye ve Aybastı ilçeleri yine kendi aralarında gruplandırılarak rotalar oluşturulabilir. Ayrıca bu ilçeler arasındaki ulaşım olanakları iyileştirilerek turistlerin kısa zaman diliminde daha fazla çekiciliği ziyaret edebilmesine olanak sağlanabilir. Çekicilik çeşitliliğinin yüksek olduğu Perşembe ilçesi ise zaten kendi başına bir çekim merkezi olduğundan bu noktada reklam-tanıtım faaliyetleri ve otel hizmetleri için daha fazla yatırım yapmak iyi birer seçenek olacaktır.

\subsubsection{Ulaşılabilirlik ile İlgili Öneriler}

Ulaşılabilirlik kategorisi değerlendirmesi incelendiğinde tüm ilçelere asfalt yolla ve tüm araç türleriyle ulaşılabildiği görülmektedir. Tüm araçlarla ulaşılabilen ancak yer yer bozuk asfalt yapısına sahip Çaybaşı ve İkizce ilçelerinde ise yolların onarılarak kaliteli asfalt yapısına kavuşturulması turizm açısından son derece önemlidir. Zaten viraj sayısının fazla olması nedeniyle ulaşım zaman alırken buna asfalttaki bozuklukların da eklenmesi erişimi son derece zorlaştırmaktadır. Malum ilkbahar aylarında özellikle yüksek rakıma sahip yayla yollarında kar erimeleri ve suların yüzeysel akışa geçmesi kimi zaman yollarda tahribatlara sebep olabilmektedir. Bu nedenle ilçelerin yolları, özellikle de yüksek rakım değerine sahip yollar belirli aralıklarla kontrol edilerek herhangi bir problem olması durumunda müdahale edilmesi şarttır. Ordu Büyükşehir Belediyesi tarafından bisiklet kiralama sistemi kullanıma sunulmuştur. Çok sayıda kişi tarafından kullanılmaya başlayan bu sistemin yanında yurtdışında kullanılan saatlik araç kiralama sistemi de il genelinde uygulamaya konulabilir. Bu sistemde il genelinde park alanları bulunan kiralık araçlar tıpkı bisiklet sisteminde olduğu gibi bir yerden teslim alınıp farklı bir yerde bırakılabilmektedir. Bu sayede tüm gün araç kiralamak istemeyen turistler aracı teslim aldıktan birkaç saat sonra ulaştıkları yerde aracı park ederek kullandıkları kadar ödeme yapmaktadır. Bu sistemin otoparkları çok rağbet gören turistik çekiciliklerin bulunduğu alanlarda da yer alabilir. Örneğin; Ordu-Giresun Havalimanı'ndan teslim alınan bir araç Çambaşı Yaylası'nda teslim edilebilir ve bu şekilde otelde konakladıkları süre boyunca turistler araç kirası ödeme yükünden kurtulmuş olur. Ayrıca turistik çekiciliklerle ilgili detaylı bilgileri içerisinde barındıran ve sadece turizm ile ilgili bir mobil uygulama hazırlanabilir. Hazırlanabilecek bu uygulamaya ait bilgi görselleri (indirme kare kodu vb.) havalimanı ve otogar gibi şehir ulaşımı için son derece önemli noktalara yerleştirilebilir. Böylece turistlerin Ordu’ya ayak basar basmaz bir rehbere sahip olması sağlanabilir. Ayrıca bu uygulama içerisinde ulaşım olanaklar1, ulaşım araçları ile ilgili zaman ve güzergâh bilgilerine yer verilebilir. Ya da araç kiralama firmalarının konum bilgileri bulunabilir. Ordu Büyükşehir Belediyesi'nin mobil uygulaması içerisinde 
Hatipoğlu, Ş. C. (2021). Ordu ilinin doğaya dayalı turizm olanaklarının "doğa temelli turizm için doğal kaynakların ölçümü modeli” ile değerlendirilmesi, Mavi Atlas, 9(2), 92-107

turistik çekiciliklerle ilgili bir bölüm bulunmaktadır. Ancak bu bölümde yer alan bilgiler detaylı ve fark edilebilir değildir.

\subsubsection{Destekleyici Altyapı ile İlgili Öneriler}

Altınordu, Fatsa, Ünye, Gülyalı, Kabadüz, Perşembe ve Gölköy ilçelerinde genel anlamda bir altyapı sorunu görünmemektedir. Ancak yine de Gülyalı ilçesinde barbekü altyapısının geliştirilmesi gerekmektedir. Ayrıca Kabadüz, Gölköy Aybastı ve Ulubey ilçelerinde engelliler için erişim altyapısı mutlaka oluşturulmalıdır. Akkuş ilçesi için piknik masaları ve engelli erişim altyapısına ihtiyaç duyulmakta olup özellikle engelli erişimi altyapısı acil sağlanmalıdır. Çamaş ve Gürgentepe ilçeleri için barbekü ve engelli erişimi altyapıları oluşturulmalıdır. Kumru, Korgan, Çaybaşı ve ikizce ilçeleri için piknik masaları, barbekü ve engelli erişimi gibi çok sayıda altyapı eksikliği mevcut olduğundan bunlar mutlaka giderilmelidir. Çatalpınar ve Kabataş ilçeleri için ise piknik masaları, oturaklar/banklar, barbekü ve engelli erişimi altyapıları eksik olduğundan mutlaka bu destek altyap1 elemanlarının tamamlanması gereklidir. Ordu ili geneline uygulanan yöntem sonucu en problemli ilçelerin Çatalpınar ve Kabataş ilçeleri olduğu görülmüştür. Eksiklikler sebebiyle bu ilçelere ziyaret edebilecek turist sayısında azalma dahi gözlenebilir. Bundan dolayı eksik altyapı ve destek sistemleri mutlaka tamamlanmalıdır.

\subsection{4. Çevresel Bozulma ile İlgili Öneriler}

Çevresel bozulma kategorisinde bazı ilçelerde problemler mevcuttur. Çaybaşı özellikle çöp problemi yaşamaktadır. Yapımı yakın süre içinde tamamlanan katı atık tesisinden sızan sular çevreye zarar vermektedir. Gerekli önlemlerin alınarak tesisin istikrarlı hale getirilmesi şarttır. Kabadüz'de ise özellikle Çambaşı Yaylası ve çevre obalarda giderek artan yapılaşmalar, yörede doğa üzerindeki baskıyı arttırmaktadır. Bu yapılaşmalar mutlaka kontrol altında tutulmalı, izinsiz yapılaşmaya kesinlikle müsaade edilmemelidir. Mutlaka yapılaşma gerekiyorsa da sürdürülebilir bir biçimde ve doğal yapıyı bozmayacak şekilde olmalıdır. Korgan ilçesinde geçmişten günümüze yaşanan heyelanlar çevresel bozulma bakımından ilçedeki en önemli problemdir (Yılmaz vd., 2013, s. 383). Özellikle kanalizasyon ve su şebekesi incelenerek yer altına suların sızması önlenmeli ve yüzey suları da en kısa yoldan vadi tabanlarına ulaştırılmalıdır (Yılmaz vd., 2013, s. 393). Yine Aybastı ilçesinde yaşanan heyelanlar çevresel bozulma açısından ilçe için olumsuzluk yaratmaktadır (Hatipoğlu vd., 2021, s. 58). Bu nedenle heyelan risk analizleri yapılarak riskin yüksek olduğu bölgeler kullanıma kapatılmalıdır.

Ordu ilinde doğaya dayalı turizm bakımından kaynak çeşitliliğinin yüksek olduğu görülebilmektedir. Çalışmada tespit edilen eksikliklerin giderilmesiyle doğaya dayalı turizmin Ordu ilinde daha fazla gelişim göstermesi sağlanabilir. Ayrıca yapılan önerilerin dikkate alınması yöreye gelebilecek turist sayısının artmasına katkılar sağlayacaktır.

\section{Kaynakça}

Acuner, E. \& Tayfun, A. (2016). Doğa temelli erişilebilir turizm: Rize örneği (Naturenased accessible tourism: case of Rize). Journal of Tourism and Gastronomy Studies, 4(2), 63-93. https://www.jotags.org/2016/vol4 issue2 article4.pdf

Arslan, E. S. (2019). Burdur'da doğa turizmi ile ilişkili alternatif rotaların belirlenmesi. International Journal of Geography and Geography Education, 40, 332-346. https://doi.org/10.32003/iggei.570310

Bahadır, M. \& Işı1k, M. (2018). Perşembe Yaylasında (Ordu) jeomorfositler ve turizm amaçlı kullanımları. Kapadokya Yerbilimleri Sempozyumu (24-26 Ekim) Tam Metin Bildiriler Kitabı 2, (ss. 92-97), Niğde.

Bahtiyar Karadeniz, C. (2014). Sürdürülebilir turizm kapsamında sakin şehir Perşembe. Uluslararasi Sosyal Araștirmalar Dergisi, 7(29), 84-107. 
Hatipoğlu, Ş. C. (2021). Ordu ilinin doğaya dayalı turizm olanaklarının "doğa temelli turizm için doğal kaynakların ölçümü modeli” ile değerlendirilmesi, Mavi Atlas, 9(2), 92-107

Bahtiyar Karadeniz, C., Kabacık, M. \& Sarı, S. (2018). Ordu ilinde ekoturizm uygulamalar1, Kabakdağ, Kayabaşı örneği. Karabülk Üniversitesi Sosyal Bilimler Enstitüsü Dergisi, 8(2), 323-337.

Bahtiyar Karadeniz, C. \& Sarı, S. (2018). Ordu ilinin doğal kaynaklara dayalı turizm potansiyelinin değerlendirilmesi. Uluslararası Sosyal Araştırmalar Dergisi, 11(61), 741-759. http://dx.doi.org/10.17719/jisr.2018.2968

Boo, E. (1990). Ecotourism: potentials and pitfalls (Vol. 1). World Wildlife Fund.

Doğaner, S. (1994). Köyceğiz-Dalyan çevresinde eko-turizm. Türkiye Kalkımma Bankası Turizm Yallŭg, 94-106.

Fredman, P. \& Margaryan L. (2021). 20 years of nordic nature-based tourism research: a review and future research agenda. Scandinavian Journal of Hospitality and Tourism, 21(1), 14-25. https://doi.org/10.1080/15022250.2020.1823247

Güler, S. (2021). Ordu ilinin ekoturizm potansiyelinin değerlendirilmesi. Turizm Ekonomisi, Yönetimi ve Politika Araștormalar, 1(1), 55-72.

Hatipoğlu, Ş. C. \& Bahadır M. (2020). Altınordu (Ordu) ilçesindeki jeosit ve jeomorfositlerin turizm potansiyellerinin "Preliminary Geosite Assessment Model (GAM)" ile ölçümü. Mavi Atlas, 8(2), 548-564. https://doi.org/10.18795/gumusmaviatlas.790874

Hatipoğlu, İ. K., Uzun, A., Zeybek, H. İ. \& Hatipoğlu Ş. C. (2021). Sağlik Mahallesi heyelanı (Ordu, Türkiye). Jeomorfolojike Arastermalar Dergisi, 6, 56-66. https://doi.org/10.46453/jader.811124

Koday, S., Kaymaz, H. \& Kaya, G. (2018). Kuzalan Tabiat Parkı'nın doğa turizm potansiyeli (Dereli-Giresun)". Marmara Coğrafya Dergisi, 37, 124-143. https://doi.org/10.14781/mcd.386171

Koday, S. \& Kızılkan, Y. (2018). Ünye ilçe merkezi'nin doğal ve kültürel turizm değerleri İçinde Prof. Dr. Süleyman Uyar (Ed.), Uluslararası Sosyal, İdari ve Beşeri Bilimler Semposyumu Bildirileri (ss. 94-108). Asos Yayınevi.

Köroğlu, Ö. \& Kahraman, S. (2014). Doğaya dayalı turizm faaliyetlerinin gelişiminde toplum temelli doğal kaynak yönetiminin önemi. KMÜ Sosyal ve Ekonomik. Arasttrmalar Dergisi, 16(26), 95-106. https://doi.org/10.18493/kmusekad.05157

Luzar, E. J., Diagne, A., Gan, C. \& Henning B. R. (1995). Evaluating nature-based tourism using the new environmental paradigm. Journal of Agricultural and Applied Economics, 27(2), 544-555.

Pirselimoğlu Batman, Z. \& Demirel, Ö. (2015). Altındere Vadisi Meryemana Deresi güzergâhında doğa temelli turizm etkinliği: Yamaç paraşütü. İnönü Üniversitesi Sanat ve Tasarm Dergisi, 5(11), 13-26.

Priskin, J. (2001). Assessment of natural resources for nature-based tourism: the case of the Central Coast Region of Western Australia. Tourism management, 22(6), 637-648. https://doi.org/10.1016/S0261-5177(01)00039-5

Şengül, F., Akyüz, H. \& Uca, S. (2019). Doğal kaynaklara dayalı turizm: Ordu ili ve Jukkasjarvi örnekleri. Bayburt Üniversitesi İnsan ve Toplum Bilimleri Fakültesi Dergisi, Özel Say1 5, 23-34.

Turoğlu, H. \& Özdemir, H. (2005). Bartın ilinin ekoturizm potansiyelinin belirlenmesi. Doğu Coğrafja Dergisi, 10(13), 97-116.

Verbos, R. I., Altschuler, B. \& Brownlee, M. T. J. (2017). Weather studies in outdoor recreation and nature-based tourism: a research synthesis and gap analysis. Leisure Sciences, 40(2), 1 24. https://doi.org/10.1080/01490400.2017.1325794 
Hatipoğlu, Ş. C. (2021). Ordu ilinin doğaya dayalı turizm olanaklarının "doğa temelli turizm için doğal kaynakların ölçümü modeli” ile değerlendirilmesi, Mavi Atlas, 9(2), 92-107

Weaver, D., Faulkner, B. \& Lawton, L. (1999). Nature-based tourism in Australia and beyond: a preliminary investigation. CRC for Sustainable Tourism, Report 1, 1-30.

Winter, P. L., Selin, S., Cerveny, L. \& Brecker, K. (2019). Outdoor recreation, naturebased tourism, and sustainability. Sustainability, 12(81), 1-12. https://doi.org/10.3390/su12010081

Yılmaz, C., Uzun, A. \& Zeybek, H. İ. (2013). Korgan ilçe merkezi heyelanları (Ordu). İçinde H. Korkmaz \& A. Karataş (Eds.) III. Ulusal Jeomorfoloji Sempozyumu Bildiriler Kitabı (ss. 382394). Renk Ofset. 